\title{
Genetic assessment of hyperuricemia and gout in Asian, Native Hawaiian, and Pacific Islander subgroups of pregnant women: biospecimens repository cross-sectional study
}

\author{
Ali Alghubayshi ${ }^{1}$, Alison Edelman ${ }^{2}$, Khalifa Alrajeh $^{1}$ and Youssef Roman ${ }^{*}$
}

\begin{abstract}
Background: Gout, an inflammatory condition, is characterized by the precipitation of monosodium urate crystals (MSU) in or around distal joints. The latter is caused by chronic hyperuricemia (HU) - high urate levels in the blood. Genetic variations in urate transporters play a significant role in determining urate levels within the human body, rendering some racial and ethnic groups more or less susceptible to developing either $\mathrm{HU}$ or gout. This study aims to estimate the frequencies of $\mathrm{HU}$ and gout risk alleles in Asian, Native Hawaiian, and Pacific Islander subgroups, using biorepository DNA samples.

Methods: The biospecimens repository at the University of Hawai'i provided DNA samples of consented post-partum women of Japanese, Filipino, Korean, Native Hawaiian, Samoan, and Marshallese descent. The DNA was previously extracted from maternal blood and genotyped at the Genomics and Bioinformatics Shared Resource, Cancer Center (Honolulu, HI). Nine urate genes: ABCG2, SLC2A9, SLC16A9, GCKR, SLC22A11, SLC22A12, LRR16A, PDZK1, and SLC17A1, were selected due to their significant association with $\mathrm{HU}$ and gout risk. Hardy-Weinberg Equilibrium (HWE) for genotype frequencies was assessed, using the Chi-Square test with $p<0.006$ for statistical significance. Allele frequencies in our study were then compared to EUR from the 1000 Genomes Project Database Phase III, using Chi-square or Fisher's exact test, when appropriate. Bonferroni correction for multiple comparisons was used, with $p<0.006$ for statistical significance.

Results: Our study involved 1059 post-partum women 18-year-old or older who self-reported their respective race and ethnicity, including Asian, Native Hawaiian, and Pacific Islander ancestry. The Asian subgroups included Japanese, Filipino, and Korean. The Pacific Islander subgroups included Marshallese and Samoan. None of the study participants had a history of gout. We excluded the PDZK1 gene from the final analysis due to its deviation from HWE $(p<0.006)$ across all the population subgroups, with eight loci remaining for cross-subgroup comparisons. Compared to EUR, the genetic polymorphism frequencies were significantly different-8/8 in Japanese, 6/8 in Korean, 6/8 in Filipino, 8/8 in Samoan, 6/8 in Native Hawaiian, and 6/8 in Marshallese. HU and gout risk alleles indices were 8, 6, 5, 5, 4, and 4 in Japanese, Filipino, Korean, Samoan, Marshallese, and Native Hawaiian, respectively. The percentage of cumulative risk alleles was $100 \%$ in both Japanese and Filipino, followed by $83.5 \%$ in Korean.
\end{abstract}

\footnotetext{
*Correspondence: romany2@vcu.edu

${ }^{1}$ Department of Pharmacotherapy and Outcomes Science, School

of Pharmacy, Virginia Commonwealth University, Richmond, VA

23298-0533, USA

Full list of author information is available at the end of the article
}

(c) The Author(s) 2021. Open Access This article is licensed under a Creative Commons Attribution 4.0 International License, which permits use, sharing, adaptation, distribution and reproduction in any medium or format, as long as you give appropriate credit to the original author(s) and the source, provide a link to the Creative Commons licence, and indicate if changes were made. The images or other third party material in this article are included in the article's Creative Commons licence, unless indicated otherwise in a credit line to the material. If material is not included in the article's Creative Commons licence and your intended use is not permitted by statutory regulation or exceeds the permitted use, you will need to obtain permission directly from the copyright holder. To view a copy of this licence, visit http://creativecommons.org/licenses/by/4.0/. The Creative Commons Public Domain Dedication waiver (http://creativeco mmons.org/publicdomain/zero/1.0/) applies to the data made available in this article, unless otherwise stated in a credit line to the data. 
Conclusions: Compared to EUR, Asian subgroups, particularly Japanese, Filipino, and Korean, had the highest percentage of the cumulative uric acid risk alleles. These results could partly explain the increased risk of developing gout among some Asian ancestral subgroups compared to EUR.

Keywords: Gout, Hyperuricemia, Health disparities, Asian subgroups, Native Hawaiian, Pacific Islanders, Single nucleotide polymorphisms, Pregnancy, Race, Ethnicity

\section{Background}

Gout is one of the most common inflammatory arthritic conditions characterized by the precipitation of monosodium urate crystals (MSU) in or around distal joints [1]. Chronically elevated serum urate (SU), a condition known as hyperuricemia (HU), is the culprit of developing gout. Acute gout flare affects monoarticular joints (e.g., knee, ankle, and metatarsophalangeal), causing severe inflammation with excruciating pain, swelling, erythema, and reduced mobility [2] The prevalence of gout in developed countries is higher than the developing ones. In the United States (US), gout prevalence is up to $3.9 \%$ affecting about 9.2 million people. Gout and hyperuricemia prevalence varies by sex and age groups. Also, specific racial and ethnic subgroups tend to have distinct $\mathrm{HU}$ and gout prevalence, ushering the notion of population-specific risk and suggesting distinct $\mathrm{HU}$ and gout allele frequencies across different racial and ethnic groups.

Many factors play different roles in regulating SU levels and might lead to HU and gout [3]. Genetic polymorphisms in urate transporters, mainly single nucleotide polymorphisms (SNPs), have been implicated in developing HU or gout. Numerous studies have ascertained the role of the genetic variation of urate transporters, and it estimated the heritability of urate by up to $73 \%$ [4]. One of the largest genome-wide association studies (GWAS) metanalysis, involving more than 110,000 participants from different racial backgrounds, discovered 28 loci associated with SU levels [5]. These loci are predominately in genes encoding urate transporters, including SLC2A9, ABCG2, SLC22A11, SLC22A12, SLC17A1, and the scaffolding protein-encoding gene PDZK1 [4].

Indeed, the prevalence of $\mathrm{HU}$ and gout varies among people and countries. Along with differences in the genetic background, several demographic and environmental characteristics such as diet and lifestyle, smoking, alcohol consumption, or beverages containing high amounts of fructose corn syrup may increase HU and gout prevalence [6]. Studies published since 2015 showed a substantial increase in gout incidence over recent decades in the US, Canada, Denmark, Sweden, and South Korea, confirming greater incidence in men relative to women and increased incidence in later life decades. Also, recent studies in North America and Scandinavia found a 1.5-twofold increase in gout incidence over the past two to three decades [7-12]. Gout incidence in South Korea increased by $25 \%$ between 2009 and 2015 [13]. A recent study reported that the Maori and Pacific Islanders populations in New Zealand have a gout prevalence of 7.63\% [14]. These trends indicate that gout incidence increased in many countries over recent decades and that the aging population in these countries may drive this increased gout incidence. Gout prevalence varies globally, with one of the highest prevalence in Oceanic countries, particularly in indigenous and South Pacific Island populations. Along with the rising gout prevalence earlier reported in Europe and the US, there is increasing evidence of growing prevalence in Australia (self-reported), Canada, China, and South Korea [15]. According to the US Census Bureau, Chinese and Filipino groups are considered two of the largest Asian subgroups. Similarly, Native Hawaiian and Samoan are the largest Pacific Islander subgroups [16]. Amongst all the ethnic subgroups in the US, populations with Asian ancestry are approximately three times more likely to develop gout than Europeans (EUR) [17].

There is an association between genetic polymorphisms in urate disposition and the incidence of gout amongst different ethnic groups. Therefore, the purpose of this study is to estimate the frequencies of selected SNPs in specific urate genes across diverse populations (Filipino, Japanese, Korean, Samoan, Marshallese, and Native Hawaiian) compared with the EUR population. With the growing need for racial diversity in genomic research, this study will further our understanding of the genetics of $\mathrm{HU}$ and gout in underrepresented population subgroups. We hypothesized that the risk allele frequencies of $\mathrm{HU}$ and gout are significantly higher in the Asian, Native Hawaiian, and Pacific Islander subgroups compared with the EUR population.

\section{Methods \\ Study participants and urate genes}

Participants included in this study were pregnant women aged 18-year-old or older. All participants self-reported $100 \%$ of their respective race/ethnicity, indicated by both biological parents and four grandparents being of the same race/ethnicity. We excluded participants with a history of cancer or 
organ transplant. The uric acid gene/SNPs pairs included: SLC17A1 (rs1183201), PDZK1 (rs12129861), SLC22A11 (rs17300741), ABCG2 (rs2231142), SLC16A9 (rs2242206), SLC22A12 (rs505802), SLC2A9 (rs734553), LRRC16A (rs742132), GCKR (rs780094).

\section{Sample procurement and genotyping}

DNA samples with limited medical and demographics information of study participants were provided by the University of Hawai'i biospecimens repository. Historically, these samples were collected after obtaining written consent. The placenta and umbilical cord of the participants were collected as part of the routine care. DNA extraction was conducted on maternal blood samples, and genotyping was carried out at the Genomics and Bioinformatics Shared Resource, Cancer Center (Honolulu, HI). A customized TaqMan genotyping assay panel was run on the Quant Studio 12K Flex Real-Time PCR system (Applied Biosystems). All study details were previously published [18]. All study materials were reviewed and exempted by the University of Hawai'i Human Studies Program (Protocol Number: 2018-00225).

\section{Statistical analysis}

Continuous variables were summarized as means ( \pm standard deviation); categorical variables were summarized as counts and percentages (\%). Allele frequencies of our population subgroups were compared with EUR, using Chi-square or Fisher's exact test, when appropriate. Bonferroni correction was used for multiple comparisons with $p<0.006$ for statistical significance. Deviation from Hardy-Weinberg Equilibrium in our selected genetic polymorphisms was assessed using Chi-square test with $p<0.006$ for statistical significance. Ensemble genome browser was used to estimate the allele and genotype frequencies of the EUR population (Referent group). In our analysis, we defined the urate risk allele as the allele associated with baseline or higher risks of developing $\mathrm{HU}$ or gout. The data analysis was performed using SPSS Statistics for Windows, version 23 (IBM SPSS, IBM Corp., Armonk, N.Y., USA).

\section{Results}

Study participants characteristics and demographics In this study, 1059 participants were included. Demographic characteristics of all participants are shown in Table 1. The participant's age ranged from 18 to 47 years with a means of 29 years. The gestational age ranged from

Table 1 Demographic characteristics across ancestral subgroups

\begin{tabular}{|c|c|c|c|c|c|c|c|}
\hline Characteristics & $\begin{array}{l}\text { Total } \\
\text { population } \\
(n=1059)\end{array}$ & Filipino $(n=229)$ & $\begin{array}{l}\text { Japanese } \\
(n=210)\end{array}$ & $\begin{array}{l}\text { Samoan } \\
(n=200)\end{array}$ & $\begin{array}{l}\text { Marshallese } \\
(n=160)\end{array}$ & $\begin{array}{l}\text { Native } \\
\text { Hawaiian } \\
(n=156)\end{array}$ & Korean $(n=104)$ \\
\hline $\begin{array}{l}\text { Mother's age } \\
\text { (years) }\end{array}$ & $28.8 \pm 6.3$ & $29.8 \pm 6.1$ & $33.4 \pm 5.2$ & $26.3 \pm 5.7$ & $25.1 \pm 4.6$ & $26.2 \pm 5.5$ & $31.3 \pm 5.2$ \\
\hline $\begin{array}{l}\text { Gestational age } \\
\text { (weeks) }\end{array}$ & $38.0 \pm 2.2$ & $37.8 \pm 2.2$ & $37.6 \pm 2.6$ & $38.4 \pm 2.0$ & $38.0 \pm 2.0$ & $38.2 \pm 2.0$ & $38.3 \pm 2.4$ \\
\hline \multicolumn{8}{|l|}{$\begin{array}{l}\text { Gestational age } \\
\text { category }\end{array}$} \\
\hline $\begin{array}{l}\text { Preterm } \\
(<37 \text { weeks })\end{array}$ & 182 (17.3\%) & 44 (19.4\%) & $50(23.8 \%)$ & $27(13.5 \%)$ & $29(18.4 \%)$ & $21(13.5 \%)$ & $11(10.8 \%)$ \\
\hline $\begin{array}{l}\text { Full term } \\
(\geq 37 \text { weeks) }\end{array}$ & $871(82.2 \%)$ & $183(80.6 \%)$ & $160(76.2 \%)$ & 173 (86.5\%) & $129(81.6 \%)$ & $135(86.5 \%)$ & $91(89.2 \%)$ \\
\hline $\begin{array}{l}\text { Body mass index } \\
\left(\mathrm{kg} / \mathrm{m}^{2}\right)\end{array}$ & $26.3 \pm 6.9$ & $25.0 \pm 6.0$ & $24.4 \pm 5.6$ & $30.1 \pm 7.5$ & $25.1 \pm 6.2$ & $28.1 \pm 7.3$ & $24.5 \pm 7.2$ \\
\hline \multicolumn{8}{|l|}{$\begin{array}{l}\text { Body mass index } \\
\text { categories }\end{array}$} \\
\hline $\begin{array}{l}\text { Underweight } \\
\left(<18.5 \mathrm{~kg} / \mathrm{m}^{2}\right)\end{array}$ & $63(6.8 \%)$ & $18(9.0 \%)$ & $20(10.4 \%)$ & $5(2.9 \%)$ & $10(7.8 \%)$ & - & $10(11.5 \%)$ \\
\hline $\begin{array}{l}\text { Normal weight } \\
\left(18.5-24.9 \mathrm{~kg} / \mathrm{m}^{2}\right)\end{array}$ & 400 (43.4\%) & $94(46.8 \%)$ & $93(48.4 \%)$ & $44(25.3 \%)$ & $68(53.1 \%)$ & $58(41.4 \%)$ & $43(49.4 \%)$ \\
\hline $\begin{array}{l}\text { Overweight } \\
\left(25-29.9 \mathrm{~kg} / \mathrm{m}^{2}\right)\end{array}$ & $211(22.9 \%)$ & $56(27.9 \%)$ & $46(24.0 \%)$ & $38(21.8 \%)$ & $18(14.1 \%)$ & $30(21.4 \%)$ & $23(26.4 \%)$ \\
\hline $\begin{array}{l}\text { Obese }(\geq 30 \mathrm{~kg} / \\
\left.\mathrm{m}^{2}\right)\end{array}$ & 248 (26.9\%) & $33(16.4 \%)$ & $33(17.2 \%)$ & 87 (50.0\%) & $32(25.0 \%)$ & $52(37.1 \%)$ & $11(12.6 \%)$ \\
\hline $\begin{array}{l}\text { Pre- gravida } \\
\text { weight (lbs) }\end{array}$ & $151.2 \pm 46.5$ & $132.7 \pm 28.4$ & $127.2 \pm 26.0$ & $203.7 \pm 44.7$ & $142.5 \pm 41.9$ & $166.9 \pm 47.9$ & $133.6 \pm 34.5$ \\
\hline
\end{tabular}


24 to 41 weeks with a means of 38 weeks, of which $82.2 \%$ $(\mathrm{n}=871)$ were full term and $17.3 \%(\mathrm{n}=182)$ were preterm. Using the pregravida weight, the body mass index (BMI) ranged from 24.5 to $30.1 \mathrm{~kg} / \mathrm{m}^{2}$, with a means of $26.3 \mathrm{~kg} / \mathrm{m}^{2}$, of which $43.4 \%(\mathrm{n}=400)$ were classified as having normal weight, $26.9 \%(n=248)$ were classified as obese, $22.9 \%(n=211)$ were classified as overweight, and $6.8 \%(n=63)$ were classified as underweight. Our study consisted of $21.5 \%$. $(n=229)$ Filipinos, $19.8 \%(n=210)$ Japanese, $18.9 \% \quad(n=200) \quad$ Samoans, $15.1 \% \quad(n=160)$ Marshallese, 14.7\% ( $\mathrm{n}=156)$ Native Hawaiian, and 9.8\% $(\mathrm{n}=104)$ were Koreans. No subjects reported a history of gout.

\section{Hyperuricemia and gout risk alleles frequencies}

Table 2 describes the role of select SNPs within specific uric acid genes. Risk alleles and genotype frequencies of all nine uric acid genes/SNP pairs in all ethnic subgroups are summarized in Tables 3 and 4. Briefly, the prevalence of the $\mathrm{T}$ allele of rs2231142 (G> T) in ABCG2 was $9.4 \%$ in EUR, $45.8 \%$ in Filipinos, $27.8 \%$ in Koreans, and 25.6\% in Japanese. Furthermore, in the NHPI subgroups, the frequencies of the $\mathrm{T}$ allele were $31.1 \%, 17.6 \%$, and $12.7 \%$ in Samoan, Marshallese, and Native Hawaiian, respectively. The T allele of the rs734553 (G> T) in SLC2A9 was higher in Asian and Pacific Islander population subgroups than in EUR. Specifically, the frequency of the $\mathrm{T}$ allele of the rs734553 (G>T) was 99.5\% in Japanese, 98.8\% in Filipinos, and $98.3 \%$ in Koreans compared to $75.5 \%$ in EUR. Additionally, the frequency of rs734553 (G > T) was 100\% in Marshallese, $98.3 \%$ in Samoan, and $90.9 \%$ in Native Hawaiians compared to $75.5 \%$ in EUR.

The prevalence of the A allele of $\operatorname{rs1183201}(\mathbf{T}>A)$ in SLC17A1 was lower in Asian subgroups, Native Hawaiian, and Samoan than EUR descent. Marshallese, however, had a significantly higher prevalence (57.2\%) than EUR (46.1\%) $(p=0.002)$. Amongst the Asian subgroups, the frequency of the A allele of the rs1183201 ( T > A) in SLC17A1 was 2-3-folds lower than that in EUR $(14.6 \%, 17.1 \%$, and $20.9 \%$ for Koreans, Japanese, and Filipinos respectively vs. 46.1\%). The A allele of the rs $17300741 \mathrm{G}>\mathbf{A}$ in SLC22A11 in Asian subgroups of Korean, Filipino, and Japanese, was about twofold higher than EUR (89.6\%, 85.3\%, and 84.7\%, respectively vs. $46.2 \%$ in $\operatorname{EUR}(p<0.00001)$.

The frequency of the A allele of $\mathrm{rs} 17300741 \mathrm{G}>\mathrm{A}$ in SLC22A11 was higher in Samoan, Native Hawaiian, and Marshallese than EUR $(78.5 \%, 72.3 \%$, and $70 \%$, respectively, vs. $46.2 \%$ in EUR $(p<0.00001)$. In SLC16A9, the Asian subgroups (Koreans, Japanese, and Filipinos) had the highest prevalence of the $\mathrm{T}$ allele, which is approximately two times higher than EUR (59.2\%, 55.5\%, and $45 \%$, respectively, vs. $26.6 \%, p<0.00001)$. Additionally, the prevalence of the risk allele $\mathrm{T}$ in Native Hawaiian (45.1\%), Marshallese (44.5\%), and Samoan (39.3\%) were significantly higher compared with EUR (26.6\%) $(p<0.00001)$. The remaining allele frequencies across all subgroups are summarized in Tables 3 and 4.

In the Japanese cohort, eight out of the eight uric acid alleles significantly differed from EUR (Table 5). All these eight alleles $(100 \%)$ were prevalent in the Japanese population from EUR and were considered risk alleles. These risk alleles included: rs1183201 $\mathbf{T}>\mathrm{A}$ in SLC17A1, rs2231142 G > T in ABCG2, rs2242206 G > T in SLC16A9, rs505802 $\mathbf{C}>\mathrm{T}$ in $S L C 22 A 12, r s 734553 \mathrm{G}>\mathrm{T}$ in $S L C 2 A 9$, rs17300741G $>\mathbf{A}$ in $S L C 22 A 11, \quad$ rs742132 $\mathbf{A}>\mathrm{G}$ in $L R R C 16 A$, and rs780094 C $>\mathbf{T}$ in GCKR.

In the Korean cohort, six out of the eight uric acid SNPs significantly differed from EUR (Table 5). Five out of the six alleles (83.5\%) were more prevalent in Korean than EUR and were considered risk alleles. These risk alleles genes/SNPs included: $r$ 1183201 $\mathbf{T}>\mathrm{A}$ in SLC17A1, rs2242206 G>T in SLC16A9, rs505802 C> T in $S L C 22 A 12, \operatorname{rs} 734553 \mathrm{G}>\mathbf{T}$ in $S L C 2 A 9, \operatorname{rs} 17300741$ $\mathrm{G}>\mathbf{A}$ in $S L C 22 A 11$.

In the Filipino cohort, six out of the eight uric acid SNPs significantly differed from EUR (Table 5). All these six SNPs in Filipino were more prevalent (100\%) than EUR and were considered risk alleles. These genes/SNPs included: rs1183201 T > A in SLC17A1, rs2231142 G> T in $A B C G 2, \mathrm{rs} 2242206 \mathrm{G}>\mathbf{T}$ in $S L C 16 A 9$, rs505802 $\mathbf{C}>\mathrm{T}$ in $S L C 22 A 12, \mathrm{rs} 734553 \mathrm{G}>\mathbf{T}$ in $S L C 2 A 9$, and rs17300741 $\mathrm{G}>\mathbf{A}$ in SLC22A11.

In the Marshallese cohort, six out of the eight uric acid SNPs significantly differed from EUR (Table 5). Among those six SNPs, the Marshallese population had four uric acid alleles significantly more prevalent (66.5\%) than EUR and were considered risk alleles. These genes/SNPs included: rs2231142 $\mathbf{G}>\mathbf{T}$ in $A B C G 2$, rs2242206 $\mathbf{G}>\mathbf{T}$ in $S L C 16 A 9$, rs505802 $\mathrm{C}>\mathrm{T}$ in $S L C 22 A 12$, and rs734553 $\mathrm{G}>\mathrm{T}$ in $S L C 2 A 9$.

In the Samoan cohort, eight out of the eight urate SNPs significantly differed from EUR (Table 5). Among those eight SNPs, five uric acid alleles (62.5\%) had a higher prevalence in the Samoan population than EUR and were considered risk alleles. These genes/SNPs included: rs2231142 $\mathrm{G}>\mathbf{T}$ in $A B C G 2$, rs505802 $\mathbf{C}>\mathrm{T}$ in $S L C 22 A 12$, rs734553 G> T in SLC2A9, rs17300741 G>A in SLC22A11, rs1183201 T > A in SLC17A1.

In the Native Hawaiian cohort, six out of the eight uric acid SNPs were significantly different from EUR (Table 5). Four out of six alleles (66.5\%) were more prevalent in the Native Hawaiian population than EUR, and were considered risk alleles. These genes/SNPs include: rs505802 C > T in SLC22A12, rs734553 G > T in SLC2A9, rs17300741 G>A in $S L C 22 A 11$, and $\operatorname{rs1183201} \mathbf{T}>\mathbf{A}$ in 


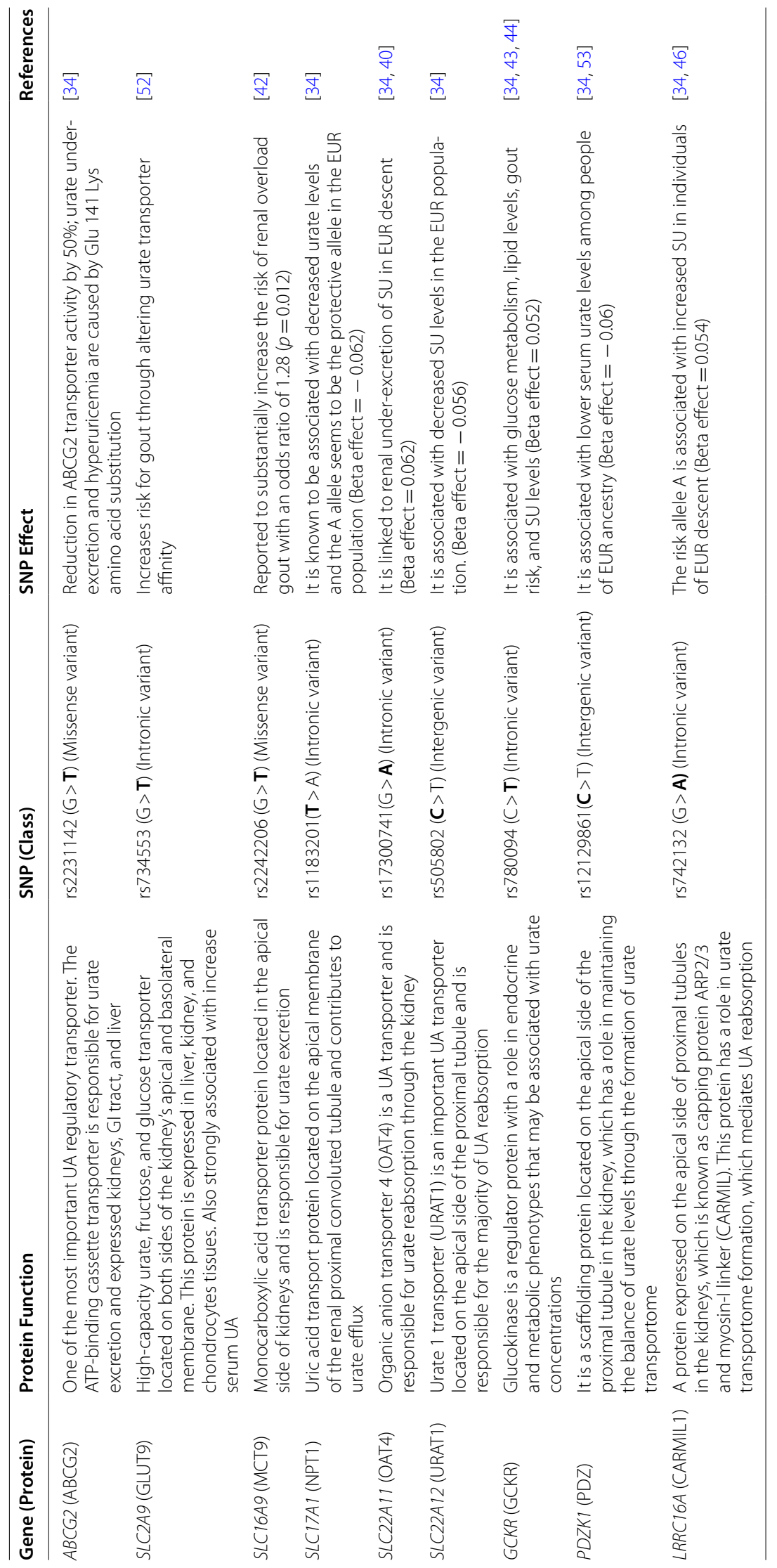




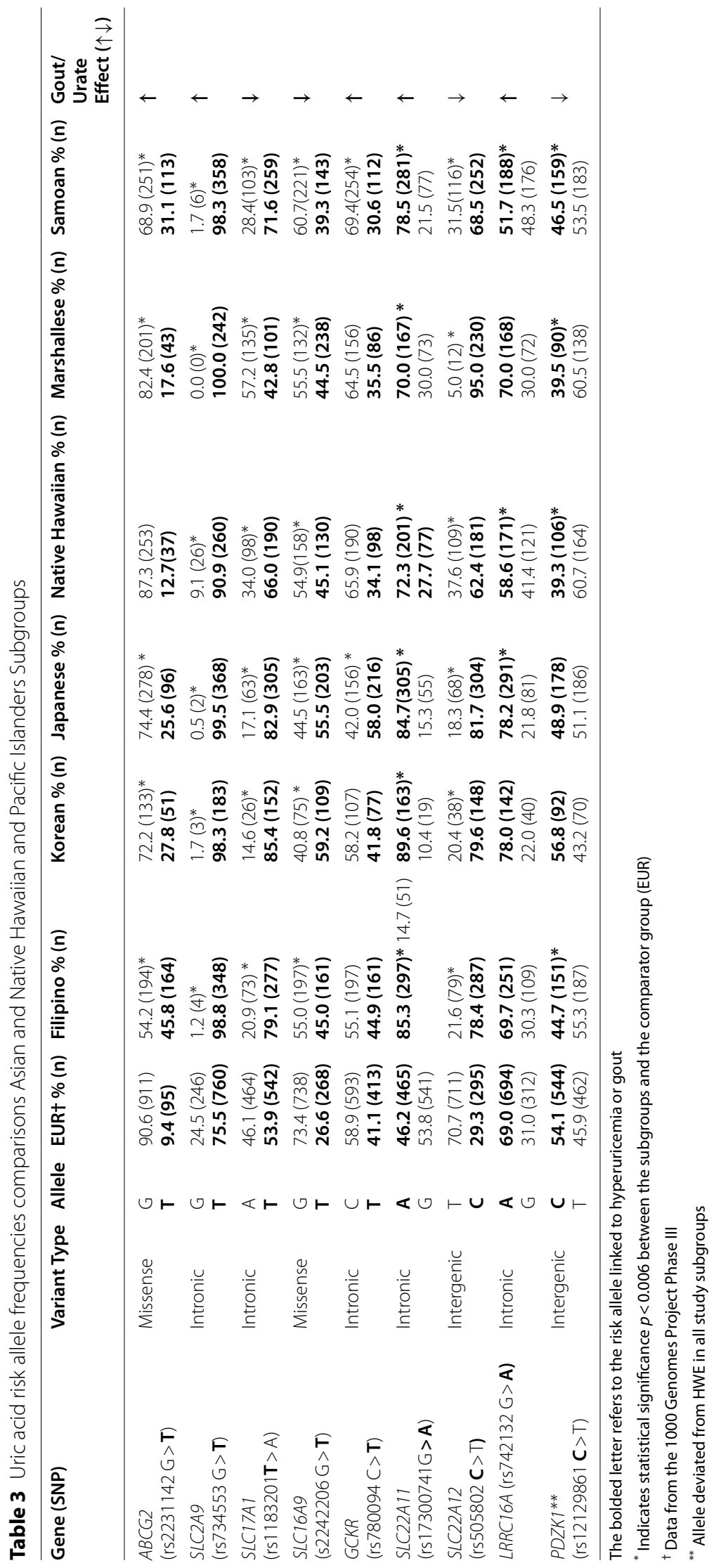


Table 4 Uric acid Genotype frequencies comparisons Asian, Native Hawaiian, and Pacific Islanders Subgroups

\begin{tabular}{|c|c|c|c|c|c|c|c|c|}
\hline Gene (SNP) & Genotype & EURT \% (n) & Filipino \% (n) & Korean \% (n) & Japanese \% (n) & $\begin{array}{l}\text { Native } \\
\text { Hawaiian } \\
\%(n)\end{array}$ & Marshallese \% (n) & Samoan \% (n) \\
\hline $\begin{array}{l}A B C G 2 \\
(\mathrm{rs} 2231142 \mathrm{G}>\mathbf{T})\end{array}$ & $\begin{array}{l}\text { GG } \\
\text { GT } \\
\text { TT }\end{array}$ & $\begin{array}{l}82.3(414) \\
16.5(83) \\
1.2(6)\end{array}$ & $\begin{array}{l}28.4(51) \\
51.4(92) \\
20.1(36)\end{array}$ & $\begin{array}{l}56.5(52) \\
31.5(29) \\
12.0(11)\end{array}$ & $\begin{array}{l}56.7(106) \\
35.3(66) \\
8.0(15)\end{array}$ & $\begin{array}{l}75.5(110) \\
23.1(33) \\
1.4(2)\end{array}$ & $\begin{array}{l}68.0(83) \\
28.7(35) \\
3.3(4)\end{array}$ & $\begin{array}{l}48.9(89) \\
40.1(73) \\
11(20)\end{array}$ \\
\hline $\begin{array}{l}\text { SLC2A9 } \\
(\mathrm{rs} 734553 \mathrm{G}>\mathbf{T})\end{array}$ & $\begin{array}{l}\mathrm{GG} \\
\mathrm{GT} \\
\mathrm{TT}\end{array}$ & $\begin{array}{l}5.6(28) \\
37.8(190) \\
56.6(285)\end{array}$ & $\begin{array}{l}- \\
2.3(4) \\
97.7(172)\end{array}$ & $\begin{array}{l}- \\
3.2(3) \\
96.8(90)\end{array}$ & $\begin{array}{l}- \\
1.1(2) \\
98.9(183)\end{array}$ & $\begin{array}{l}1.4(2) \\
15.4(22) \\
83.2(119)\end{array}$ & $\begin{array}{l}- \\
- \\
100(121)\end{array}$ & $\begin{array}{l}- \\
3.3(6) \\
96.7(176)\end{array}$ \\
\hline $\begin{array}{l}\text { SLC17A1 } \\
(\mathrm{rs} 1183201 \mathbf{T}>A)\end{array}$ & $\begin{array}{l}\text { AA } \\
\text { AT } \\
\text { TT }\end{array}$ & $\begin{array}{l}23.1(116) \\
46.1(232) \\
30.8(155)\end{array}$ & $\begin{array}{l}4.0(7) \\
33.7(59) \\
62.3(109)\end{array}$ & $\begin{array}{l}1.1(1) \\
27.0(24) \\
71.9(64)\end{array}$ & $\begin{array}{l}3.8(7) \\
26.6(49) \\
69.6(128)\end{array}$ & $\begin{array}{l}11.8(17) \\
44.4(64) \\
43.8(63)\end{array}$ & $\begin{array}{l}29.7(35) \\
55.0(65) \\
15.3(18)\end{array}$ & $\begin{array}{l}6.6(12) \\
43.7(79) \\
49.7(90)\end{array}$ \\
\hline $\begin{array}{l}\text { SLC16A9 (rs2242206 } \\
\text { G>T) }\end{array}$ & $\begin{array}{l}\text { GG } \\
\text { CT } \\
\text { TT }\end{array}$ & $\begin{array}{l}54.9(276) \\
37.0(186) \\
8.1(41)\end{array}$ & $\begin{array}{l}32.9(59) \\
44.1(79) \\
23.0(41)\end{array}$ & $\begin{array}{l}15.2(14) \\
51.1(47) \\
33.7(31)\end{array}$ & $\begin{array}{l}16.9(31) \\
55.2(101) \\
27.9(51)\end{array}$ & $\begin{array}{l}34.7(50) \\
40.3(58) \\
25.0(36)\end{array}$ & $\begin{array}{l}31.9(38) \\
47.1(56) \\
21.0(25)\end{array}$ & $\begin{array}{l}33.0(60) \\
55.5(101) \\
11.5(21)\end{array}$ \\
\hline $\begin{array}{l}\text { GCKR } \\
(\text { rs } 780094 \text { C > T) }\end{array}$ & $\begin{array}{l}C C \\
C T \\
T T\end{array}$ & $\begin{array}{l}33.6(169) \\
50.7(255) \\
15.7(79)\end{array}$ & $\begin{array}{l}31.8(57) \\
46.4(83) \\
21.8(39)\end{array}$ & $\begin{array}{l}35.9(33) \\
44.6(41) \\
19.5(18)\end{array}$ & $\begin{array}{l}18.8(35) \\
46.3(86) \\
34.9(65)\end{array}$ & $\begin{array}{l}41.7(60) \\
48.6(70) \\
9.7(14)\end{array}$ & $\begin{array}{l}41.3(50) \\
46.3(56) \\
12.4(15)\end{array}$ & $\begin{array}{l}48.1(88) \\
42.6(78) \\
9.3(17)\end{array}$ \\
\hline $\begin{array}{l}\text { SLC22A11 } \\
(\text { rs } 17300741 G>A)\end{array}$ & $\begin{array}{l}\text { AA } \\
\text { AG } \\
\text { GG }\end{array}$ & $\begin{array}{l}23.5(118) \\
45.5(229) \\
31.0(156)\end{array}$ & $\begin{array}{l}73.6(128) \\
23.5(41) \\
2.9(5)\end{array}$ & $\begin{array}{l}80.2(73) \\
18.7(17) \\
1.1(1)\end{array}$ & $\begin{array}{l}71.7(129) \\
26.1(47) \\
2.2(4)\end{array}$ & $\begin{array}{l}54.0(75) \\
36.7(51) \\
9.3(13)\end{array}$ & $\begin{array}{l}53.3(64) \\
32.5(39) \\
14.2(17)\end{array}$ & $\begin{array}{l}62.6(112) \\
31.8(57) \\
5.6(10)\end{array}$ \\
\hline $\begin{array}{l}\text { SLC22A12 } \\
(\text { rs505802 C>T) }\end{array}$ & $\begin{array}{l}\text { CC } \\
\text { CT } \\
\text { TT }\end{array}$ & $\begin{array}{l}9.9(50) \\
38.8(195) \\
51.3(258)\end{array}$ & $\begin{array}{l}61.2(112) \\
34.4(63) \\
4.4(8)\end{array}$ & $\begin{array}{l}63.4(59) \\
32.3(30) \\
4.3(4)\end{array}$ & $\begin{array}{l}67.7(126) \\
28.0(52) \\
4.3(8)\end{array}$ & $\begin{array}{l}35.8(52) \\
53.1(77) \\
11.1(16)\end{array}$ & $\begin{array}{l}90.9(110) \\
8.3(10) \\
0.8(1)\end{array}$ & $\begin{array}{l}48.9(90) \\
39.1(72) \\
12.0(22)\end{array}$ \\
\hline $\begin{array}{l}\text { LRRC16A (rs742132 } \\
\mathrm{G}>\mathbf{A})\end{array}$ & $\begin{array}{l}\text { AA } \\
A G \\
G G\end{array}$ & $\begin{array}{l}48.3(243) \\
41.4(208) \\
10.3(52)\end{array}$ & $\begin{array}{l}48.9(88) \\
41.7(75) \\
9.4(17)\end{array}$ & $\begin{array}{l}60.4(55) \\
35.2(32) \\
4.4(4)\end{array}$ & $\begin{array}{l}62.4(116) \\
31.7(59) \\
5.9(11)\end{array}$ & $\begin{array}{l}30.2(44) \\
56.8(83) \\
13.0(19)\end{array}$ & $\begin{array}{l}51.7(62) \\
36.7(44) \\
11.6(14)\end{array}$ & $\begin{array}{l}25.2(46) \\
52.8(96) \\
22.0(40)\end{array}$ \\
\hline $\begin{array}{l}\text { PDZK1** } \\
(\text { rs12129861 C > T) }\end{array}$ & $\begin{array}{l}\text { CC } \\
\text { CT } \\
\text { TT }\end{array}$ & $\begin{array}{l}30.4(153) \\
47.3(238) \\
22.3(112)\end{array}$ & $\begin{array}{l}42(71) \\
5.4(9) \\
52.6(89)\end{array}$ & $\begin{array}{l}54.3(44) \\
4.9(4) \\
40.8(33)\end{array}$ & $\begin{array}{l}47.8(87) \\
2.2(4) \\
50.0(91)\end{array}$ & $\begin{array}{l}36.3(49) \\
5.9(8) \\
57.8(78)\end{array}$ & $\begin{array}{l}37.7(43) \\
3.5(4) \\
58.8(67)\end{array}$ & $\begin{array}{l}42.2(72) \\
8.7(15) \\
49.1(84)\end{array}$ \\
\hline
\end{tabular}

The bolded letter refers to the risk allele linked to hyperuricemia or gout

${ }^{\dagger}$ Data from the 1000 Genomes Project Phase III

${ }^{*}$ Allele deviated from HWE in all study subgroups

Table 5 Summary of Total Risk Alleles across Asian, Native Hawaiian, and Pacific Islanders Subgroups

\begin{tabular}{|c|c|c|c|c|c|c|c|}
\hline & EUR & Japanese & Korean & Filipino & Marshallese & Native Hawaiian & Samoan \\
\hline $\begin{array}{l}\text { Total alleles significantly differ- } \\
\text { ent from EUR }\end{array}$ & Reference (8 SNPs) & $100 \%(8 / 8)$ & $75 \%(6 / 8)$ & $75 \%(6 / 8)$ & $75 \%(6 / 8)$ & $75 \%(6 / 8)$ & $100 \%(8 / 8)$ \\
\hline HU or/gout risk allele index* & & 8 & 5 & 6 & 4 & 4 & 5 \\
\hline Percentage of risk allele* & & $100 \%(8 / 8)$ & $83.5 \%(5 / 6)$ & $100 \%(6 / 6)$ & $66.5 \%(4 / 6)$ & $66.5 \%(4 / 6)$ & $62.5 \%(5 / 8)$ \\
\hline
\end{tabular}

${ }^{*}$ Indicates the risk allele that contributes to hyperuricemia or gout

EUR European

SLC17A. Among all our studied cohorts, Japanese, Filipino, and Korean subgroups had the highest $\mathrm{HU}$ and gout risk allele indices of 8,6 , and 5 , respectively. The percentages of risk alleles were $100 \%$ in Japanese and Filipino, $83.5 \%$ in Korean, 66.5\% in Native Hawaiian and Marshallese, and $62.5 \%$ in Samoan (Table 5).

\section{Genetic analysis and quality control}

As a measure of quality control, genetic results were assessed for Hardy-Weinberg Equilibrium (HWE), using chi-square with Bonferroni corrected $p<0.006$ for significance (Table 6). SNPs call rates were evaluated and reported for each ethnic group and the overall study cohort ( $\mathrm{n}=1059$ participants). Overall SNPs call rate were $97.4 \%$ in $S L C 22 A 12,95.1 \%$ in SLC17A1, 96\% in $S L C 16 A 9,96.9 \%$ in $A B C G 2,94.3$ in $S L C 22 A 11$, 91\% in PDZK1, 96.1\% in $S L C 2 A 9,96.4 \%$ in $L R R C 16 A$, and $96.7 \%$ in GCKR (Table 7). 
Table 6 Hardy Weinberg Equilibrium (HWE) Assessment of Targeted SNPs

\begin{tabular}{|c|c|c|c|c|c|c|}
\hline Gene/SNP & Filipino & Japanese & Samoan & Marshallese & Native Hawaiian & Korean \\
\hline $\begin{array}{l}\text { SLC17A1 } \\
\text { (rs1183201) }\end{array}$ & 0.7789 & 0.4036 & 0.3326 & 0.1743 & 0.9035 & 0.4449 \\
\hline $\begin{array}{l}\text { PDZK1*** } \\
\text { (rs12129861) }\end{array}$ & 0.0000 & 0.0000 & 0.0000 & 0.0000 & 0.0000 & 0.0000 \\
\hline $\begin{array}{l}\text { SLC22A11 } \\
\text { (rs17300741) }\end{array}$ & 0.4439 & 0.9076 & 0.4465 & 0.0109 & 0.3224 & 0.9926 \\
\hline $\begin{array}{l}A B C G 2 \\
\text { (rs } 2231142)\end{array}$ & 0.6376 & 0.3044 & 0.3942 & 0.8952 & 0.7880 & 0.0407 \\
\hline $\begin{array}{l}\text { SLC16A9 } \\
\text { (rs2242206) }\end{array}$ & 0.1473 & 0.1129 & 0.0275 & 0.6046 & 0.0250 & 0.5789 \\
\hline $\begin{array}{l}\text { SLC22A12 } \\
\text { (rs505802) }\end{array}$ & 0.8183 & 0.3809 & 0.2042 & 0.1753 & 0.1123 & 0.9398 \\
\hline $\begin{array}{l}\text { SLC2A9 } \\
\text { (rs734553) }\end{array}$ & 0.8788 & 0.9410 & 0.8211 & 0.0000 & 0.4077 & 0.8743 \\
\hline $\begin{array}{l}\text { LRRC16A } \\
\text { (rs742132) }\end{array}$ & 0.8602 & 0.3476 & 0.4492 & 0.1642 & 0.0384 & 0.8089 \\
\hline $\begin{array}{l}\text { GCKR } \\
\text { (rs780094) }\end{array}$ & 0.3981 & 0.4903 & 0.9620 & 0.9112 & 0.3209 & 0.4184 \\
\hline
\end{tabular}

** Indicates deviation from HWE $p<0.006$

Table 7 SNPs Call Rate (\%)

\begin{tabular}{|c|c|c|c|c|c|c|c|c|c|}
\hline & $\begin{array}{l}\text { SLC22A12 } \\
\text { (rs505802) }\end{array}$ & $\begin{array}{l}\text { SLC17A1 } \\
\text { (rs1183201) }\end{array}$ & $\begin{array}{l}\text { SLC16A9 } \\
\text { (rs2242206) }\end{array}$ & $\begin{array}{l}A B C G 2 \\
(r s 2231142)\end{array}$ & $\begin{array}{l}\text { SLC22A11 } \\
\text { (rs17300741) }\end{array}$ & $\begin{array}{l}\text { PDZK1 } \\
\text { (rs12129861) }\end{array}$ & $\begin{array}{l}\text { SLC2A9 } \\
\text { (rs734553) }\end{array}$ & $\begin{array}{l}\text { LRRC16A } \\
\text { (rs742132) }\end{array}$ & $\begin{array}{l}\text { GCKR } \\
\text { (rs780094) }\end{array}$ \\
\hline Filipino & 96.3 & 92.1 & 94.2 & 94.2 & 91.5 & 88.9 & 92.6 & 94.7 & 94.7 \\
\hline Japanese & 98.4 & 97.3 & 96.8 & 98.9 & 95.2 & 96.2 & 97.8 & 98.4 & 98.4 \\
\hline Korean & 97.9 & 93.6 & 95.9 & 96.8 & 95.7 & 85.2 & 97.8 & 95.7 & 96.8 \\
\hline Native Hawaiian & 99.3 & 98.6 & $98 . .6$ & 99.3 & 95.2 & 92.4 & 97.9 & 98.6 & 98.6 \\
\hline Marshallese & 93.8 & 91.4 & 92.2 & 94.6 & 93.0 & 88.3 & 93.7 & 93.0 & 93.7 \\
\hline Samoan & 98.4 & 96.7 & 97.3 & 97.3 & 97.3 & 91.4 & 97.3 & 97.3 & 97.8 \\
\hline Overall & 97.4 & 95.1 & 96.0 & 96.9 & 94.3 & 91.0 & 96.1 & 96.4 & 96.7 \\
\hline
\end{tabular}

\section{Discussion}

Our study found that the post-partum women of Asian ancestry had a higher prevalence of $\mathrm{HU}$ or gout risk alleles when compared to EUR. Specifically, all significantly different uric acid alleles between the Japanese and Filipino cohorts compared with EUR, were all considered HU or gout risk alleles. These results could partially explain the differential prevalence of $\mathrm{HU}$ and gout across different ethnic and racial groups based on their genetic makeup. Therefore, a discussion on the role of these various genes/alleles in developing HU or gout is warranted.

ABCG2 gene encodes the ATP-Binding Cassette G-protein transporter located on the apical membrane in the proximal renal tubule, and it is expressed in the gastrointestinal tract and liver. ABCG2 is a major urate excretion transporter [19]. Genetic polymorphisms in the $A B C G 2$ were reported to contribute to elevated urate levels leading to $\mathrm{HU}$ and gout. The risk allele $\mathrm{T}$ of the rs2231142 $\mathrm{G}>\mathbf{T}(\mathrm{Q} 131 \mathrm{~K})$ in $A B C G 2$ is associated with increased urate levels. Individuals with the TT genotype are at higher risk for $\mathrm{HU}$ and gout than their GG counterparts. A recent study reported that the $\mathrm{T}$ allele is 3times higher in East Asians than in EUR. This prevalence suggests that East Asian populations are at higher risk for developing $\mathrm{HU}$ and gout [20].

The genetic polymorphism rs22131142 $(\mathrm{G}>\mathrm{T})$ in $A B C G 2$ is significantly associated with a higher risk for $\mathrm{HU}$ and gout among different populations [21-23]. A study conducted in a Korean cohort showed that the rs22131142 $(\mathrm{G}>\mathrm{T})$ is strongly associated with gout risk (Odds ratio [OR] 3.32; 95\% confidence interval [CI]: 2.11 to 5.20) [24]. Also, a study of 6881 Koreans identified that the genetic polymorphism rs2231142 $(\mathrm{G}>\mathrm{T})$ was associated with increased SU levels (Effect size $=0.220$, $p=2.06 \mathrm{E}-29$ ) [25]. Consistent with our results, a study reported that the minor allele frequency (MAF) of the risk allele $\mathrm{T}$ of the rs2231142 in ABCG2 was high in Japanese and Koreans compared to Caucasians $(0.29,0.28$, 
vs. 0.11) [26]. Additionally, a meta-analysis conducted on a multi-ethnic cohort reported that the $\mathrm{T}$ allele of the rs22131142 (G>T) in ABCG2 was strongly associated with $\mathrm{HU}$ and gout across different ethnic groups and further modulates the severity and gout onset [27]. While genetic polymorphism in $A B C G 2$ increases the risk for developing gout in the population at large, genetic polymorphism in $A B C G 2$ exerts different effect sizes between sexes. Specially, gene-sex interaction exists for $A B C G 2$, with effect allele exerting greater influence on gout risk in men than women [28].

Overall, the genetic polymorphism rs2231142 $(\mathrm{G}>\mathrm{T})$ in the $A B C G 2$ gene is considered the most significant genetic polymorphism in developing $\mathrm{HU}$ or gout in multiple populations compared with other uric acid risk alleles. Sun et al. evaluated the impact of 11 genetic loci of which $A B C G 2$ rs2231142 $(\mathrm{G}>\mathrm{T})$ was one of the genes associated with serum urate concentrations in the Chinese population [29]. Also, Zhang et al. reported that the SNP rs2231142 of the $A B C G 2$ gene was associated with $\mathrm{HU}$ in the American population consisting of EUR Americans, African Americans, Mexican Americans, and Indian Americans [30]. Our finding suggests that the rs2231142 (G>T) in ABCG2 may increase urate levels and gout risk in Asian and Pacific Islander subgroups compared to EUR.

SLC2A9 encodes the GLUT9 transporter with highcapacity for urate, fructose, and glucose (Table 2). SLC2A9 is known to be strongly associated with urate regulation in the human body [31]. It is mainly expressed in the kidneys and liver, but it is also expressed in human articular cartilage [32]. The intronic polymorphism rs734553 (G>T) in SLC2A9 is associated with an increased risk for $\mathrm{HU}$ and gout resulting from a change in transporter affinity for urate [33]. This genetic variation strongly affects SU levels in EUR ancestry, specifically EUR women (Effect size $=0.315, p=5.22 \times 10-201$ ) [34]. Reginato Am et al. have identified that polymorphism rs734553 in the SLC2A9 gene is linked to SU levels and gout in the Polynesian population [35]. The prevalence of the $\mathrm{T}$ allele of the rs734553 $(\mathrm{G}>\mathrm{T})$ in our Asian and NHPI subgroups was significantly higher than in EUR, suggesting that carrying the $\mathrm{T}$ allele will likely increase the risk of $\mathrm{HU}$ in both the Asian and NHPI subgroups.

SLC17A1 encodes the voltage-gated human sodiumdependent phosphate co-transporter type 1 protein (NPT1), located on the proximal tubule's apical side in the kidney and works as renal urate efflux transporter. Decreased SU levels were found to be associated with the genetic polymorphism rs1183201 ( $\mathbf{T}>\mathrm{A})$ in SLC17A1 (Effect size $=-0.062,95 \% \mathrm{CI}:-0.078 ;-0.459)$ with the effect allele $\mathrm{A}$, as the protective allele in EUR descent (Table 2). The polymorphism $\operatorname{rs} 1183201 \quad(\mathbf{T}>A)$ in
SLC17A1was associated with decreased SU levels with a prevalence of $48.2 \%$ in EUR descent [34]. Amongst our Asian subgroups, the frequency of the A allele in the rs1183201 ( $\mathbf{T}>\mathrm{A})$ was 2-3-folds lower than EUR (Table 3). The significant differences in the A allele frequencies across the population subgroups, mostly Asian subgroups, suggest that some ethnic groups could be inherently predisposed to high urate levels.

SLC22A12 encodes URAT1 transporter, a protein expressed on the kidney's apical side of the proximal convoluted tubule. This transporter is responsible for the majority of the urate reabsorption and is a primary target for urate-lowering therapies [36]. A previous study reported that the loss of function of URAT1 could cause hypouricemia in a Japanese cohort, suggesting that URAT1 plays an essential role in regulating the urate tubular reabsorption [37]. The intergenic polymorphism rs505802 $(\mathbf{C}>\mathrm{T})$ in SLC22A12 was observed to reduce urate levels in individuals of EUR ancestry. Specifically, the $\mathrm{T}$ allele was associated with lower SU levels in women and men (Effect size $=-0.073$ and -0.047 , respectively) [34]. Jang et al. reported that the $\mathrm{T} 6092 \mathrm{C}$ genetic variant in $S L C 22 A 12$ was also significantly associated with $\mathrm{SU}$ concentration amongst the male Korean population [38]. The T6092C at rs1529909 of SLC22A12 was found in nearly complete linkage disequilibrium with rs505802 of SLC22A12 ( $\left.\mathrm{D}^{\prime}=0.99, \mathrm{R}^{2}=0.98\right)$. The prevalence of the $\mathrm{T}$ allele in our population subgroups was significantly lower than EUR, with 3-4-folds lower in Asian and NHPI subgroups (Table 3). These findings suggest that Asian and NHPI population subgroups could have higher baseline urate levels compared with EUR. The frequency of the $C$ allele in Marshallese, however, was more than three times compared to EUR ( $95 \%$ vs. $29.3 \%, p<0.00001)$. These results further suggest a higher risk for $\mathrm{HU}$ and gout in Marshallese and a possible implication in the response to treatments targeting URAT1 transporter in Asian and NHPI subgroups.

$S L C 22 A 11$ is predominantly expressed on the proximal tubule's apical side in the kidney and encodes the organic anion transporter 4 (OAT4) (Table 2). The primary role of the organic anion transporter 4 (OAT4) is urate reabsorption. Like the URAT1 transporter, OAT4 is a target for urate-lowering therapy [39]. The SNP rs17300741 $(\mathrm{G}>\mathbf{A})$ in the $S L C 22 A 11$ was associated with renal urate underexcretion type gout in the Japanese population $(p=0.049)$ [40]. Kolz et al. have also reported a significant association between the polymorphism rs17300741 G > A in SLC22A11 and urate levels in individuals of Caucasian descent $(p=6.7 \times 10-14)$ [34]. Moreover, previous reports demonstrated the association between the rs17300741 G > A in gout prevalence, which is two-fold higher in non-EURs relative to EUR [41]. Our 
analysis found that the prevalence of the A allele was higher across all selected subgroups than EUR (Table 3). Our analysis of the rs $17300741 \mathrm{G}>\mathbf{A}$ in $S L C 22 A 11$ suggests a higher genetic risk for $\mathrm{HU}$ or gout in Asian and NHPI subgroups compared with EUR. Collectively, our analysis demonstrates that the frequencies of risk alleles $\mathrm{C}$ and A in both loci-SLC22A12 and SLC22A11, respectively, were significantly higher in Filipino, Korean, Japanese, Samoan, Marshallese, and Native Hawaiian relative to EUR (Table 3). Notably, the prevalence of risk alleles rs505802 $(\mathbf{C}>\mathrm{T})$ of $S L C 22 A 12$ and $\operatorname{rs} 17300741(\mathrm{G}>\mathbf{A})$ of $S L C 22 A 11$ genes were highest in Asian subgroups compared with the NHPI population.

SLC16A9 encodes for monocarboxylic acid transporter protein across the cell membrane (MCT9). It is located on the proximal tubule's apical side of the kidney and is responsible for urate excretion. A missense variant rs2242206 (G>T) in the SLC16A9 has been reported to dysregulate the urate level (Table 2). The exact function of the MCT9 transporter is still unclear. Nonetheless, Nakayama et al. have found a significant relationship between the rs2242206 G>T (K258T) in SLC16A9, and gout $(p=0.012)$, with 1.28 OR in a Japanese population [42]. Our cohort analysis showed that the frequency of $\mathrm{T}$ allele across the subgroups was significantly higher than that of EUR ancestry (Table 3). These findings suggest that individuals of Asian descent carrying the polymorphism rs2242206 (G>T) in SLC16A9 could be at higher risk for and more susceptible to gout, especially in individuals of Japanese, Korean, and Filipino descent.

GCKR encodes glucokinase regulatory protein (GCKR), which exerts a significant role in developing the components of the metabolic syndrome, including triglyceride levels and glucose metabolism (Table 2) [43, 44]. Earlier studies have demonstrated the relationship between urate levels and metabolic syndrome-related traits such as insulin resistance and hypertension through oxidative stress and inflammatory pathway [34]. The SNP rs780094 $(\mathrm{C}>\mathbf{T})$ in $G C K R$ is strongly associated with gout in the male Han-Chinese population [45]. Furthermore, the $\mathrm{T}$ allele of the rs780094 $\mathrm{C}>\mathrm{T}$ is associated with urate concentration in EUR ancestry [34]. Meanwhile, the MAF of the $\mathrm{C}$ allele was higher in the Korean cohort compared with Caucasians (0.47 vs. 0.42) [26]. In our analysis, the frequency of the $\mathrm{T}$ allele was higher only in the Japanese cohort than EUR ( $58 \%$ vs. $41.1 \%, p<0.00001$ ) and only lower in Samoan than EUR (30.6 vs. 41.1\%, $p<0.006)$ (Table 3). There was no significant difference in the $\mathrm{T}$ allele between Filipino and Korean compared to EUR. These results suggest that Japanese individuals could be at a higher risk for developing $\mathrm{HU}$, gout, and gout-related comorbidities compared with EUR. Noteworthy, the GCKR protein is associated with modulating some metabolic functions; hence, this finding might partially suggest a biological mechanism for developing cardiometabolic disorders, including $\mathrm{HU}$ and gout. Theoretically, the SNP rs780094 $(\mathrm{C}>\mathrm{T})$ could be a plausible candidate to study the intersection of urate levels and the excess risk of developing both gestational diabetes and hypertension among pregnant women of Asian ancestry.

$L R R 16 A$ is expressed on the apical side of the proximal tubule in the kidney and encodes the capping protein ARP2/3 and myosin-I linker (CARMIL) (Table 2). This protein has a role in urate transportome formation, which mediates urate reabsorption $[34,46]$. Hiraka Ogata et al. have found a significant association between the intergenic variant homozygote AA in $\operatorname{rs} 742132(\mathrm{G}>\mathrm{A})$ in $L R R C 16 A$ and the risk of gout disease among Japanese males [47]. Moreover, a genetic variant rs742132 $(\mathrm{G}>\mathrm{A})$ in $L R R C 16 A$ is associated with increased SU in EUR ancestry [34]. Notably, a GWAS conducted on an East Asian population, including Korean, showed that rs742132 in $L R R C 16 A$ is associated with elevated urate levels [48]. Amongst our population subgroups, only the Japanese cohort had a significant difference and the highest frequency of the A allele compared to EUR $(78.2 \%$, vs. $69 \%, p=0.0009)$. On the other hand, the Samoan cohort had a significantly lower frequency of the A allele compared with EUR $(51.7 \%$, vs. $69 \%$, $p<0.00001$ ) (Table 3). Asian subgroups of Japanese and Korean had the highest A allele frequency compared to all other subgroups in this study, which are consistent with previous reports [49]. Our findings suggest that the genetic polymorphism rs742132 $(\mathrm{G}>\mathrm{A})$ in LRRC16A may explain the differential prevalence of $\mathrm{HU}$ or gout risk in Asian subgroups.

Our results have collectively shown that the frequency of $\mathrm{HU}$ or gout risk alleles in several population subgroups significantly differs from EUR $(p<0.006)$. We found that the Asian subgroups had the highest $\mathrm{HU}$ or gout risk allele prevalence compared with the NHPI subgroups. These results are consistent with the patient claims data of the ambulatory care clinics that gout diagnosis in the Asian population living in the U.S. is about three times more than EUR. Consistent with the previous reports, our results provide more evidence that individuals of Asian descent have a higher risk for developing HU or gout than EUR [22, 50, 51]. We believe our analysis has broadened our understanding of gout genetic risk in select underrepresented population subgroups in biomedical research, allowing for greater delineation of populaiton-specific risk for $\mathrm{HU}$ or gout.

\section{Limitations}

First, the study was a retrospective analysis conducted only on pregnant women. Therefore, prospective 
representative samples of the population are needed to validate our findings. Second, we believe that other factors such as certain social and dietary habits, older age, and male sex significantly contribute to developing $\mathrm{HU}$ and gout; therefore, our participants represented the lowest risk profile for gout development, explaining the lack of gout diagnosis in our study cohort. Nonetheless, our genetic assessment of $\mathrm{HU}$ and gout are directionally consistent with the epidemiology of gout risk in certain racial groups. Third, we had a limited number of SNPs in our analysis, recognizing that other genes/SNPs are associated with the development of HU and gout. However, our limited SNPs were based on robust GWAS. Fourth, our study participants did not have measured SU levels to conduct an association analysis between genotype and phenotype. Finally, some of our subgroups could have benefited from larger sample sizes to estimate specific risk allele frequencies. Therefore, we believe future studies and broader genetic assessment are needed.

\section{Conclusions}

Our analysis identified that $\mathrm{HU}$ and gout risk alleles were significantly more frequent in Asian subgroups (Japanese, Filipino, and Korean) than in EUR. These findings are consistent with our previous report suggesting that Japanese and Han-Chinese populations had the highest prevalence of gout or HU risk alleles than EUR [22]. Our genetic assessment of $\mathrm{HU}$ and gout risk alleles in Asian, Native Hawaiian, and Pacific Islander subgroups highlights the distinct within-population differences, especially among subgroups generally aggregated as one race or ethnicity. Consistent with gout epidemiology, pregnant women and childbearing age women are unlikely to develop gout, despite having the genetic risk. To this end, this study reported no gout cases among our study participants.

\section{Clinical research perspective}

Genetic assessment in ancestral subgroups could play a crucial role in addressing ongoing health disparities, including gout and gout-related comorbidities. Our results not only suggest that genetic data may explain gout epidemiology but may be utilized to improve patient treatment outcomes by predicting disease risk and selecting the proper treatment. Indeed, this study is the first genetic investigation focusing on several urate genes/ SNPs pairs in multiple underrepresented ancestral subgroups of pregnant women. Our findings could advance future research to assess the effects of hormonal changes during pregnancy on urate genes expression and the role of $\mathrm{HU}$ and gout risk alleles in pregnancy outcomes such as gestation diabetes, gestation hypertension, and pre-eclampsia.

\section{Abbreviations}

SU: Serum urate; HU: Hyperuricemia; SNP: Single nucleotide polymorphism; NHANES: National Health and Nutrition Examination Survey; GWAS: GenomeWide Association Studies; EUR: European; NHPI: Native Hawaiian and Pacific Islander; CVD: Cardiovascular disease; IR: Insulin resistance; MAF: Minor allele frequency; HWE: Hardy-Weinberg equilibrium.

\section{Acknowledgements \\ This project was supported by the National Institute on Minority Health and Health Disparities U54MD007584, G12MD007601 and the National Institute General Medical Sciences P20GM103466, from the National Institutes of Health. The content is solely the responsibility of the authors and does not necessarily represent the official views of the NCRR or NIH. The authors would like to thank Drs. Joseph McClay and Elvin Price for their suggestions and feedback on study design.}

\section{Authors' contributions}

Y.R. conceived the study and provided the data. A.A. and Y.R. conducted the statistical analysis and drafted the manuscript. K.A. and A.E. reviewed the manuscript. All authors have reviewed the manuscript and agreed to the published version of the manuscript in the BMC Rheumatology Journal. All authors read and approved the final manuscript.

\section{Funding}

The authors disclosed that they did not receive any financial support to complete this study.

\section{Availability of data and materials}

All applicable and relevant data are included in the paper. Access to the raw data and biospecimens can be directed to the University of Hawaii Biorepository (http://uhbio.jabsom.hawaii.edu/Access.html).

\section{Declarations}

\section{Ethics approval and consent to participate}

All study materials were reviewed and exempted by the University of Hawai' $i$ Human Studies Program (Protocol Number: 2018-00225). Additionally, the proposal was screened through a scientific and ethical review committee for approval before any specific samples were given. Since this research was based solely on the analysis of previously collected samples, de-identified data, this study complies with the Declaration of Helsinki.

\section{Consent for publication}

Not applicable.

\section{Competing interests}

The authors declare that they have no conflict of interest.

\section{Author details}

${ }^{1}$ Department of Pharmacotherapy and Outcomes Science, School of Pharmacy, Virginia Commonwealth University, Richmond, VA 23298-0533, USA. ${ }^{2}$ Department of Obstetrics and Gynecology, School of Medicine, Oregon Health Science University, Portland, OR 97239, USA.

Received: 27 June 2021 Accepted: 8 November 2021

Published online: 06 January 2022

\section{References}

1. Bardin T, Richette P. Definition of hyperuricemia and gouty conditions. Curr Opin Rheumatol. 2014;26:186-91. https://doi.org/10.1097/BOR. 0000000000000028.

2. Ragab G, Elshahaly M, Bardin T. Gout: an old disease in new perspectivea review. J Adv Res. 2017:8:495-511. https://doi.org/10.1016/j.jare.2017. 04.008 .

3. Merriman T, Terkeltaub R. PPARGC1B: insight into the expression of the gouty inflammation phenotype: PPARGC1B and gouty inflammation. Rheumatology (Oxford). 2017;56:323-5. https://doi.org/10.1093/rheum atology/kew453. 
4. Dalbeth N, Stamp LK, Merriman TR. The genetics of gout: Towards personalised medicine? BMC Med. 2017;15:108. https://doi.org/10.1186/ s12916-017-0878-5.

5. Köttgen A, Albrecht E, Teumer A, Vitart V, Krumsiek J, Hundertmark C, et al. Genome-wide association analyses identify 18 new loci associated with serum urate concentrations. Nat Genet. 2013;45:145-54. https://doi.org/ 10.1038/ng.2500

6. Saag KG, Choi H. Epidemiology, risk factors, and lifestyle modifications for gout. Arthritis Res Ther. 2006;8:S2. https://doi.org/10.1186/ar1907.

7. Rai SK, Aviña-Zubieta JA, McCormick N, De Vera MA, Shojania K, Sayre EC, et al. The rising prevalence and incidence of gout in British Columbia, Canada: Population-based trends from 2000 to 2012. Semin Arthritis Rheum. 2017;46:451-6. https://doi.org/10.1016/j.semarthrit.2016.08.006.

8. Dehlin M, Drivelegka P, Sigurdardottir V, Svärd A, Jacobsson LTH. Incidence and prevalence of gout in Western Sweden. Arthritis Res Ther. 2016;18:164. https://doi.org/10.1186/s13075-016-1062-6.

9. Zobbe K, Prieto-Alhambra D, Cordtz R, Højgaard P, Hindrup JS, Kristensen $L E$, et al. Secular trends in the incidence and prevalence of gout in Denmark from 1995 to 2015: a nationwide register-based study. Rheumatology (Oxford). 2019;58:836-9. https://doi.org/10.1093/rheumatology/ key390.

10. Elfishawi MM, Zleik N, Kvrgic Z, Michet CJ, Crowson CS, Matteson EL, et al. Changes in the presentation of incident Gout and the risk of subsequent flares: a population-based study over 20 years. J Rheumatol. 2019. https:// doi.org/10.3899/jrheum.190346.

11. Fischer A, Cloutier M, Goodfield J, Borrelli R, Marvin D, Dziarmaga A. The direct economic burden of Gout in an elderly Canadian population. J Rheumatol. 2017;44:95-101. https://doi.org/10.3899/jrheum.160300.

12. Kapetanovic MC, Nilsson P, Turesson C, Englund M, Dalbeth $N$, Jacobsson $L$. The risk of clinically diagnosed gout by serum urate levels: results from 30 years follow-up of the Malmö Preventive Project cohort in southern Sweden. Arthritis Res Ther. 2018;20:190. https://doi.org/10.1186/ s13075-018-1697-6.

13. Kim J-W, Kwak SG, Lee H, Kim S-K, Choe J-Y, Park S-H. Prevalence and incidence of gout in Korea: data from the national health claims database 2007-2015. Rheumatol Int. 2017;37:1499-506. https://doi.org/10.1007/ s00296-017-3768-4

14. Winnard D, Wright C, Taylor WJ, Jackson G, Te Karu L, Gow PJ, et al. National prevalence of gout derived from administrative health data in Aotearoa New Zealand. Rheumatology (Oxford). 2012;51:901-9. https:// doi.org/10.1093/rheumatology/ker361.

15. Dehlin M, Jacobsson L, Roddy E. Global epidemiology of gout: prevalence, incidence, treatment patterns and risk factors. Nat Rev Rheumatol. 2020;16:380-90. https://doi.org/10.1038/s41584-020-0441-1.

16. Bureau UC. American Community Survey (ACS). The United States Census Bureau n.d. https://www.census.gov/programs-surveys/acs (accessed May 5, 2021)

17. Krishnan E, Lienesch D, Kwoh CK. Gout in ambulatory care settings in the United States. J Rheumatol. 2008;35:498-501.

18. Roman Y, Tiirikainen M, Prom-Wormley E. The prevalence of the goutassociated polymorphism rs2231142 G>T in ABCG2 in a pregnant female Filipino cohort. Clin Rheumatol. 2020;39:2387-92. https://doi.org/10. 1007/s10067-020-04994-9.

19. Bobulescu IA, Moe OW. Renal transport of uric acid: evolving concepts and uncertainties. Adv Chronic Kidney Dis. 2012;19:358-71. https://doi. org/10.1053/j.ackd.2012.07.009.

20. Liu J, Yang W, Li Y, Wei Z, Dan X. ABCG2 rs2231142 variant in hyperuricemia is modified by SLC2A9 and SLC22A12 polymorphisms and cardiovascular risk factors in an elderly community-dwelling population. BMC Med Genet. 2020;21:54. https://doi.org/10.1186/s12881-020-0987-4.

21. Lim D-H, Kim Y-G, Bae S-H, Ahn S, Hong S, Lee C-K, et al. Factors related to outcomes in lupus-related protein-losing enteropathy. Korean J Intern Med. 2015;30:906-12. https://doi.org/10.3904/kjim.2015.30.6.906.

22. Butler F, Alghubayshi A, Roman Y. The epidemiology and genetics of hyperuricemia and Gout across major racial groups: a literature review and population genetics secondary database analysis. J Pers Med. 2021. https://doi.org/10.3390/jpm11030231.

23. Yu K-H, Chang P-Y, Chang S-C, Wu-Chou Y-H, Wu L-A, Chen D-P, et al. A comprehensive analysis of the association of common variants of ABCG2 with gout. Sci Rep. 2017;7:9988. https://doi.org/10.1038/ s41598-017-10196-2.
24. Kim YS, Kim Y, Park G, Kim S-K, Choe J-Y, Park BL, et al. Genetic analysis of ABCG2 and SLC2A9 gene polymorphisms in gouty arthritis in a Korean population. Korean J Intern Med. 2015;30:913-20. https://doi.org/10. 3904/kjim.2015.30.6.913.

25. Cho SK, Kim B, Myung W, Chang Y, Ryu S, Kim H-N, et al. Polygenic analysis of the effect of common and low-frequency genetic variants on serum uric acid levels in Korean individuals. Sci Rep. 2020;10:9179. https://doi. org/10.1038/s41598-020-66064-Z.

26. Son C-N, Bang S-Y, Cho S-K, Sung Y-K, Kim T-H, Bae S-C, et al. The frequency of single nucleotide polymorphisms and their association with uric acid concentration based on data from genome-wide association studies in the Korean population. Rheumatol Int. 2014;34:777-83. https:// doi.org/10.1007/s00296-013-2939-1.

27. Dong Z, Guo S, Yang Y, Wu J, Guan M, Zou H, et al. Association between ABCG2 Q141K polymorphism and gout risk affected by ethnicity and gender: a systematic review and meta-analysis. Int J Rheum Dis. 2015;18:382-91. https://doi.org/10.1111/1756-185X.12519.

28. Narang RK, Topless R, Cadzow M, Gamble G, Stamp LK, Merriman TR, et al. Interactions between serum urate-associated genetic variants and sex on gout risk: analysis of the UK Biobank. Arthritis Res Ther. 2019;21:13. https://doi.org/10.1186/s13075-018-1787-5.

29. Sun $X$, Jiang F, Zhang $R$, Tang $S$, Chen $M$, Peng D, et al. Serum uric acid levels are associated with polymorphisms in the SLC2A9, SF1, and GCKR genes in a Chinese population. Acta Pharmacol Sin. 2014;35:1421-7. https://doi.org/10.1038/aps.2014.87.

30. Zhang L, Spencer KL, Voruganti VS, Jorgensen NW, Fornage M, Best LG, et al. Association of functional polymorphism rs2231142 (Q141K) in the ABCG2 gene with serum uric acid and gout in 4 US populations: the PAGE Study. Am J Epidemiol. 2013;177:923-32. https://doi.org/10.1093/ aje/kws330.

31. Dalbeth N, House ME, Gamble GD, Horne A, Pool B, Purvis L, et al. Population-specific influence of SLC2A9 genotype on the acute hyperuricaemic response to a fructose load. Ann Rheum Dis. 2013;72:1868-73. https:// doi.org/10.1136/annrheumdis-2012-202732.

32. Mobasheri A, Neama G, Bell S, Richardson S, Carter SD. Human articular chondrocytes express three facilitative glucose transporter isoforms: GLUT1, GLUT3 and GLUT9. Cell Biol Int. 2002;26:297-300. https://doi.org/ 10.1006/cbir.2001.0850.

33. Stark K, Reinhard W, Grassl M, Erdmann J, Schunkert H, Illig T, et al. Common polymorphisms influencing serum uric acid levels contribute to susceptibility to gout, but not to coronary artery disease. PLOS ONE. 2009:4: e7729. https://doi.org/10.1371/journal.pone.0007729.

34. Kolz M, Johnson T, Sanna S, Teumer A, Vitart V, Perola M, et al. Meta-analysis of 28,141 individuals identifies common variants within five new loci that influence uric acid concentrations. PLoS Genet. 2009;5: e1000504. https://doi.org/10.1371/journal.pgen.1000504.

35. Reginato AM, Mount DB, Yang I, Choi HK. The genetics of hyperuricaemia and gout. Nat Rev Rheumatol. 2012;8:610-21. https://doi.org/10.1038/ nrrheum.2012.144.

36. Nakanishi T, Ohya K, Shimada S, Anzai N, Tamai I. Functional cooperation of URAT1 (SLC22A12) and URATV1 (SLC2A9) in renal reabsorption of urate. Nephrol Dial Transplant. 2013;28:603-11. https://doi.org/10.1093/ndt/ gfs574.

37. Riches PL, Wright AF, Ralston SH. Recent insights into the pathogenesis of hyperuricaemia and gout. Hum Mol Genet. 2009;18:R177-184. https://doi. org/10.1093/hmg/ddp369.

38. Jang WC, Nam Y-H, Park S-M, Ahn Y-C, Park S-H, Choe J-Y, et al. T6092C polymorphism of SLC22A12 gene is associated with serum uric acid concentrations in Korean male subjects. Clin Chim Acta. 2008;398:140-4. https://doi.org/10.1016/j.cca.2008.09.008.

39. Benn CL, Dua P, Gurrell R, Loudon P, Pike A, Storer RI, et al. Physiology of hyperuricemia and urate-lowering treatments. Front Med (Lausanne). 2018;5:160. https://doi.org/10.3389/fmed.2018.00160.

40. Sakiyama M, Matsuo H, Shimizu S, Nakashima H, Nakayama A, Chiba T, et al. A common variant of organic anion transporter 4 (OAT4/ SLC22A11) gene is associated with renal underexcretion type gout. Drug Metab Pharmacokinet. 2014;29:208-10. https://doi.org/10.2133/dmpk. dmpk-13-nt-070.

41. Tj F, A P-G, Je H-M, Me M, RT, G M, et al. Association analysis of the SLC22A11 (organic anion transporter 4) and SLC22A12 (urate transporter 1) urate transporter locus with gout in New Zealand case-control sample 
sets reveals multiple ancestral-specific effects. Arthritis Research \& Therapy 2013. https://doi.org/10.1186/ar4417.

42. Nakayama A, Matsuo H, Shimizu T, Ogata H, Takada Y, Nakashima $H$, et al. Common missense variant of monocarboxylate transporter 9 (MCT9/ SLC16A9) gene is associated with renal overload gout, but not with all gout susceptibility. Hum Cell. 2013;26:133-6. https://doi.org/10.1007/ s13577-013-0073-8.

43. Fernandes Silva L, Vangipurapu J, Kuulasmaa T, Laakso M. An intronic variant in the GCKR gene is associated with multiple lipids. Sci Rep. 2019;9:10240. https://doi.org/10.1038/s41598-019-46750-3.

44. Onuma H, Tabara Y, Kawamoto R, Shimizu I, Kawamura R, Takata Y, et al. The GCKR rs780094 polymorphism is associated with susceptibility of type 2 diabetes, reduced fasting plasma glucose levels, increased triglycerides levels and lower HOMA-IR in Japanese population. J Hum Genet. 2010;55:600-4. https://doi.org/10.1038/jhg.2010.75.

45. Wang J, Liu S, Wang B, Miao Z, Han L, Chu N, et al. Association between gout and polymorphisms in GCKR in male Han Chinese. Hum Genet. 2012;131:1261-5. https://doi.org/10.1007/s00439-012-1151-9.

46. Vadakedath S, Kandi V. Probable potential role of urate transporter genes in the development of metabolic disorders. Cureus. 2018;10: e2382. https://doi.org/10.7759/cureus.2382.

47. Ogata H, Matsuo H, Sakiyama M, Higashino T, Kawaguchi M, Nakayama $\mathrm{A}$, et al. Meta-analysis confirms an association between gout and a common variant of $L R R C 16 A$ locus. Mod Rheumatol. 2017;27:553-5. https:// doi.org/10.1080/14397595.2016.1218413.

48. Okada Y, Sim X, Go MJ, Wu J-Y, Gu D, Takeuchi F, et al. Meta-analysis identifies multiple loci associated with kidney function-related traits in east Asian populations. Nat Genet. 2012;44:904-9. https://doi.org/10.1038/ng. 2352.

49. Sakiyama M, Matsuo H, Shimizu S, Chiba T, Nakayama A, Takada Y, et al. Common variant of leucine-rich repeat-containing 16A (LRRC16A) gene is associated with gout susceptibility. Hum Cell. 2014;27:1-4. https://doi. org/10.1007/s13577-013-0081-8.

50. Roman YM, Culhane-Pera KA, Menk J, Straka RJ. Assessment of genetic polymorphisms associated with hyperuricemia or gout in the Hmong. Per Med. 2016;13:429-40. https://doi.org/10.2217/pme-2016-0021.

51. Roman YM, Lor K, Xiong T, Culhane-Pera K, Straka RJ. Gout prevalence in the Hmong: a prime example of health disparity and the role of community-based genetic research. Pers Med. 2021;18:311-27. https:// doi.org/10.2217/pme-2020-0107.

52. Yi X-L, Li J, Meng D-M, Liu Y-J, Liu Y-H, Ma H-M, et al. An intron variant of SLC2A9 increases the risk for type 2 diabetes mellitus complicated with hyperuricemia in Chinese male population. Iran J Public Health. 2018:47:844-51.

53. Anzai N, Kanai Y, Endou H. New insights into renal transport of urate. Curr Opin Rheumatol. 2007;19:151-7. https://doi.org/10.1097/BOR.0b013 e328032781a.

54. Youssef, Roman The United States 2020 Census data: implications for precision medicine and the research landscape. Personalized Medicine 10.2217/pme-2021-0129

\section{Publisher's Note}

Springer Nature remains neutral with regard to jurisdictional claims in published maps and institutional affiliations.

Ready to submit your research? Choose BMC and benefit from:

- fast, convenient online submission

- thorough peer review by experienced researchers in your field

- rapid publication on acceptance

- support for research data, including large and complex data types

- gold Open Access which fosters wider collaboration and increased citations

- maximum visibility for your research: over $100 \mathrm{M}$ website views per year

At BMC, research is always in progress.

Learn more biomedcentral.com/submissions 